EVALUATION OF DIRECT-PRECIPITATION AND GAS-EVOLUTION METHODS FOR RADIOCARBON DATING OF GROUND WATER

\title{
IN CHE YANG
}

\author{
US Geological Survey, Mail Stop 407 \\ PO Box 25046, Denver Federal Center \\ Denver, Colorado 80225
}

ABSTRACT. The extraction of dissolved carbonate species for age dating from a 100L water sample by the direct-precipitation method (DPM) and by the gas-evolution method (GEM) has been investigated. Stable carbon-isotope fractionation between initial and final carbon dioxide evolved was ca $11 \%$ 。 by GEM and $1 \%$ by DPM. GEM will produce isotopically lighter carbon dioxide compared with DPM if carbonate recovery is low. Extraction efficiency of $>95 \%$ can be achieved by GEM in 3 hours using nitrogen gas at a sweeping rate of $2000 \mathrm{cc}$ per minute. DPM requires precipitates to settle overnight to assure $>95 \%$ recovery. GEM is little affected by a high concentration of sulfate ions, whereas DPM is greatly affected by sulfate resulting in less yield.

Important in the correction of ${ }^{14} \mathrm{C}$ age for ground water is estimating the contributions of various sources of dissolved carbonate species based on measured ${ }^{13} \mathrm{C} /{ }^{12} \mathrm{C}$ ratios and total carbonate. Because large fractionations were observed with a large sample, a separate small aliquot of water sample $(500 \mathrm{~m} 1)$ should be analyzed for stable carbon isotopes by DPM to assure complete extraction. For small samples ( $<1 \mathrm{ml}$ of benzene) gas counting is preferred over liquid-scintillation counting. A carbon dioxide-methane conversion can be accomplished in 3 hours with a $98 \%$ yield for a $4 \mathrm{~L}$ sample.

\section{INTRODUCTION}

Groundwater samples for ${ }^{14} \mathrm{C}$ dating at the US Geological Survey water-quality laboratory, Denver, Colorado are either collected and returned to the laboratory for carbonate precipitation or precipitated at the sampling site and shipped back for ${ }^{14} \mathrm{C}$ analysis (Thatcher, Janzer, and Edwards, 1977). Precipitation at the sampling site has the advantage of shipping small containers although it yields less carbonate precipitate because of insufficient settling time. Laboratory precipitation costs more for sample shipment and dissolved carbon dioxide $\left(\mathrm{CO}_{2}\right)$ may be lost during transportation. The precipitation method gives low carbonate yields when sulfate ions are present in high concentration. Gleason, Friedman, and Hanshaw (1969) studied the effect of carbon-isotope fractionation by 
the gas-evolution method (GEM) and the direct-precipitation method (DPM) and found that the former technique seemed to give large fractionations. The present investigation further studies the two methods with an improved gas-evolution apparatus and aims at substituting the present DPM with GEM. This will enable us to obtain a greater $\mathrm{CO} 2$ yield from carbonate species at the sampling site in less time, facilitate shipment of collected gas samples, and eliminate the problem of atmospheric $\mathrm{CO}_{2}$ contamination. The scope of the studies includes $\mathrm{CO}_{2}$ yield from carbonate species by GEM, and comparison of carbon-isotope fractionation by both methods in $100 \mathrm{~L}$ samples.

\section{GAS-EVOLUTION METHOD (GEM)}

LABORATORY STUDIES OF THE $\mathrm{CO}_{2}$ YIELD. Laboratory experiments were conducted with sodium bicarbonate $\left(\mathrm{NaHCO}_{3}\right)$ dissolved in de-ionized water and with calcium chloride $\left(\mathrm{CaCl}_{2}\right)$ and magnesium sulfate $\left(\mathrm{MgSO}_{4}\right)$ added to produce an artifical ground water. De-ionized water was purged with $\mathrm{CO}_{2}$-free nitrogen $\left(\mathrm{N}_{2}\right)$ gas to expel any dissolved $\mathrm{CO}_{2}$ in the water before dissolution of $\mathrm{NaHCO}_{3}$. Complete evolution of $\mathrm{CO}_{2}$ is achieved by addition of excess sulfuric acid $\left(\mathrm{H}_{2} \mathrm{SO}_{4}\right)$. To produce $8 \mathrm{~L}$ of $\mathrm{CO}_{2}$ at $25^{\circ} \mathrm{C}$ and $760 \mathrm{~mm} \mathrm{Hg}, 28.7 \mathrm{~g}$ of $\mathrm{NaHCO}_{3}, 7 \mathrm{~g}$ of $\mathrm{MgSO}_{4} .7 \mathrm{H}_{2} \mathrm{O}$, and $45 \mathrm{~g}$ of $\mathrm{CaCl}_{2} \cdot 2 \mathrm{H}_{2} \mathrm{O}$ are dissolved in $100 \mathrm{~L}$ of water. The water was kept in two $60 \mathrm{~L}$ carboys connected in series. $\mathrm{CO}_{2}$ was collected in two 1iquid-nitrogen-cooled traps in the laboratory vacuum-line system. The $\mathrm{N}_{2}$ sweep facilitates collection of $\mathrm{CO}_{2}$. The exit gas was bubbled through a bottle containing saturated solution of barium hydroxide $\left(\mathrm{Ba}(\mathrm{OH})_{2}\right)$ to ensure no loss of $\mathrm{CO}_{2}$. If $\mathrm{CO}_{2}$ escapes, white precipitate will be formed in the bottle. Nitrogen flow rates were controlled at two speeds: one at $2000 \mathrm{~cm}^{3} / \mathrm{min}$, and the other at $1000 \mathrm{~cm}^{3} /$ min. The rate of $\mathrm{CO}_{2}$ evolution was determined by measuring the incremental volume evolved vs elapsed time. Each volume measurement was done by expanding the $\mathrm{CO}_{2}$ collected in two liquid-nitrogen traps into a known volume of reservoirs in the vacuum-line system. The time/yield relation is shown in table 1. The data indicate that $95 \%$ or more of $\mathrm{CO}_{2}$ in water can be collected in $<2 \mathrm{hr}$ at a sweep rate of $2000 \mathrm{~cm}^{3} / \mathrm{min}$, and in 3 hr at a sweep rate of $1000 \mathrm{~cm}^{3} / \mathrm{min}$. Thus, if the $\mathrm{CO}_{2}$ recovery is $95 \%$ or more, the occurrence of carbon-isotope fractionation should be negligible for our purpose.

LABORATORY STUDIES OF CARBON-ISOTOPE FRACTIONATION. Samples for fractionation studies were collected in five fractions of approximately equal volumes of $\mathrm{CO}_{2}$ by adding theoretical amounts of acid required in each fraction. Carbon dioxide evolved in each fraction was precipitated separately in an 
TABLE 1. Time vs $\mathrm{CO}_{2}$ yield at two flow rates (carrier gas, $\mathrm{N}_{2}$, sample size of

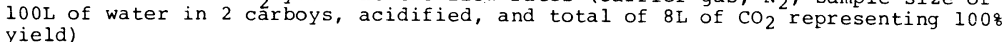

\begin{tabular}{ccc}
\hline $\begin{array}{c}\text { Flow rate of } \\
(\mathrm{cm} 3 / \mathrm{min})\end{array}$ & $\begin{array}{c}\text { Elapsed time } \\
(\mathrm{min})\end{array}$ & $\begin{array}{c}\text { Accumulated } \\
\mathrm{CO}_{2} \text { yield } \\
(8)\end{array}$ \\
\hline & 20 & 11.5 \\
1000 & 40 & 44.0 \\
& 80 & 63.0 \\
& 150 & 89.3 \\
& 180 & 95.0 \\
240 & 100.0 \\
& 10 & 4.9 \\
& 30 & 47.0 \\
& 50 & 66.1 \\
& 80 & 95.2 \\
& 110 & 100.0 \\
\hline
\end{tabular}

TABLE 2. Laboratory studies of carbon-isotope fractionation by GEM from artificial ground water. Each fraction contains ca $20 z$ of the total carbon content of the water sample*

\begin{tabular}{|c|c|c|c|c|}
\hline Water & sample** & Fraction & $\begin{array}{l}\delta^{13} \mathrm{C}\left(\%_{0}\right) \\
\text { (fractional) }\end{array}$ & $\begin{array}{c}\delta^{13} \mathrm{C}(\%) \\
\text { (accumulated) }\end{array}$ \\
\hline & 1 & $\begin{array}{l}\text { 1st } \\
2 \text { nd } \\
3 \text { rd } \\
4 \text { th } \\
5 \text { th }\end{array}$ & $\begin{array}{r}-11.3 \\
-12.0 \\
-9.0 \\
-3.3 \\
-1.8\end{array}$ & $\begin{array}{r}-11.3 \\
-11.7 \\
-10.8 \\
-8.9 \\
-7.5\end{array}$ \\
\hline & 2 & $\begin{array}{l}1 \mathrm{st} \\
2 \mathrm{nd} \\
3 \mathrm{rd} \\
4 \mathrm{th} \\
5 \mathrm{th}\end{array}$ & $\begin{array}{r}-9.2 \\
-11.9 \\
-9.7 \\
-6.5 \\
-2.1\end{array}$ & $\begin{array}{r}-9.2 \\
-10.6 \\
-10.3 \\
-9.3 \\
-7.9\end{array}$ \\
\hline
\end{tabular}

* Samples for fractionation studies were collected in five fractions of approximately equal volumes of $\mathrm{CO}_{2}$ by adding theoretical volumes of acid required in ** Water sample w

mple was prepared by dissolving $28 \mathrm{~g}$ of $\mathrm{NaHCO}_{3}$ in $100 \mathrm{~L}$ of distilled water and adding $\mathrm{CaCl}_{2}$ and $\mathrm{MgSO}_{4}$ to simulate a natural ground water.

TABLE 3. Comparison of carbon-isotope fractionation by DPM and GEM methods for water from a limestone aquifer near Gillette, Wyoming. (The precision for $\delta 13 \mathrm{C}$ values is \pm 0.28

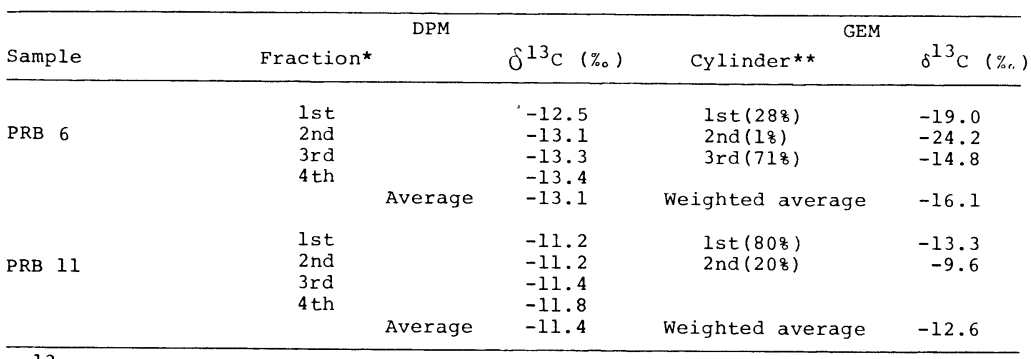

$\star \delta^{13} \mathrm{C}$ samples were precipitated in four fractions of approximately equal volumes by adding $\frac{1}{4}$ of the required amount of $\mathrm{SrCl}_{2}-\mathrm{NH}_{4} \mathrm{OH}$ solution to the sample water each time.

* Gas evolved from two carboys (60L each) was collected in a Linde $5 \mathrm{~A}$ molecular sieve contained in two $500 \mathrm{~cm}^{3}$ stainless-steel cylinders connected in series (fig 1). For sample PRB 6, first two cylinders collected the dissolved $\mathrm{CO}_{2}$ by direct purging of water sample without acidification for $30 \mathrm{~min}$ followed by replacing the first two cylinders with the third cylinder and collecting the reining carbonate by acidification. 
evacuated bottle (near vapor pressure of water) containing a saturated $\mathrm{Ba}(\mathrm{OH})_{2}$ solution. The reaction proceeded instantaneously to form barium carbonate $\left(\mathrm{BaCO}_{3}\right)$ precipitate. A smal1 portion gf mixed, dry $\mathrm{BaCO}_{3}$ was taken, acidified and analyzed for ${ }^{13} \mathrm{C} /{ }^{12} \mathrm{C}$. The results are shown in table 2 . Values of $\delta{ }^{13} \mathrm{C}$ indicate that large fractionation occurred in both studies. The tendency, as expected, is to release the lighter carbon-isotope initially and the heavier carbonisotope at the end of the studies. The maximum $\delta{ }^{13} \mathrm{differ-}$ ence-between the initial and final fractions is $10.2 \%$ in the first study and $9.8 \%$ in the second study. The accumulated ${ }^{13} \mathrm{C}$ difference between the initial and final values is ca $3.2 \%$, which is somehwat smaller compared with $5 \%$ reported by Voge1, Lerman, and Mook (1975).

SAMPLING-SITE STUDIES OF $\mathrm{CO}_{2}$ EVOLUTION. The apparatus used for $\mathrm{CO}_{2}$ evolution at sampling sites is shown in figure 1 . Water traps used in the laboratory were replaced with silica gel contained in two transparent plastic containers. Two metal cylinders $\left(500 \mathrm{~cm}^{3}\right)$ containing Linde $5 \mathrm{~A}^{1}$ molecular sieve replaced the liquid nitrogen traps for collecting $\mathrm{CO}_{2}$ (Fergusson, 1963; Fairha11, Young, and Bradford, 1972). The molecular sieve was evacuated and heated to $350^{\circ} \mathrm{C}$ under the vacuum (overnight) to remove any moisture or $\mathrm{CO}_{2}$ before use at the sampling site. At the sampling site, 100L of groundwater sample contained in two carboys were acidified with concentrated $\mathrm{H}_{2} \mathrm{SO}_{4}$. Pure $\mathrm{N}_{2}$ from a gas cylinder was slowly bubbled through the water at a flow rate of $1000 \mathrm{~cm}^{3} / \mathrm{min}$ for $30 \mathrm{~min}$, then gradually increased to $2000 \mathrm{~cm} 3 / \mathrm{min}$ and purged at this flow rate for $21 / 2 \mathrm{hr}$. To estimate the possible loss of dissolved $\mathrm{CO}_{2}$ during the sample filling process and shipment from the sampling site to the laboratory in Denver, sample PRB 6 was purged for $30 \mathrm{~min}$ at the flow rate of $1000 \mathrm{~cm}^{3} / \mathrm{min}$ without acidification and $\mathrm{CO}_{2}$ collected in two metal cylinders. Then, the first two cylinders were replaced with a third cylinder and it collected the remaining carbonate by acidification. The results are shown in table 3 . For sample $\mathrm{PRB} 6$, the $\mathrm{CO}_{2}$ collected in the first two cylinders amounted to ca $29 \%$ of total $\mathrm{CO}_{2}$. Therefore, it is advisable to adjust the $\mathrm{pH}$ of water to ca 10 by addition of fresh $\mathrm{NaOH}$ solution just before water collection, so that dissolved $\mathrm{CO}_{2}$ can be converted to carbonate species to avoid the outgassing loss during transportation if precipitation at the sampling site is not feasible.

1 The use of brand names in this report is for identification only and does not constitute endorsement by the US Geological Survey. 


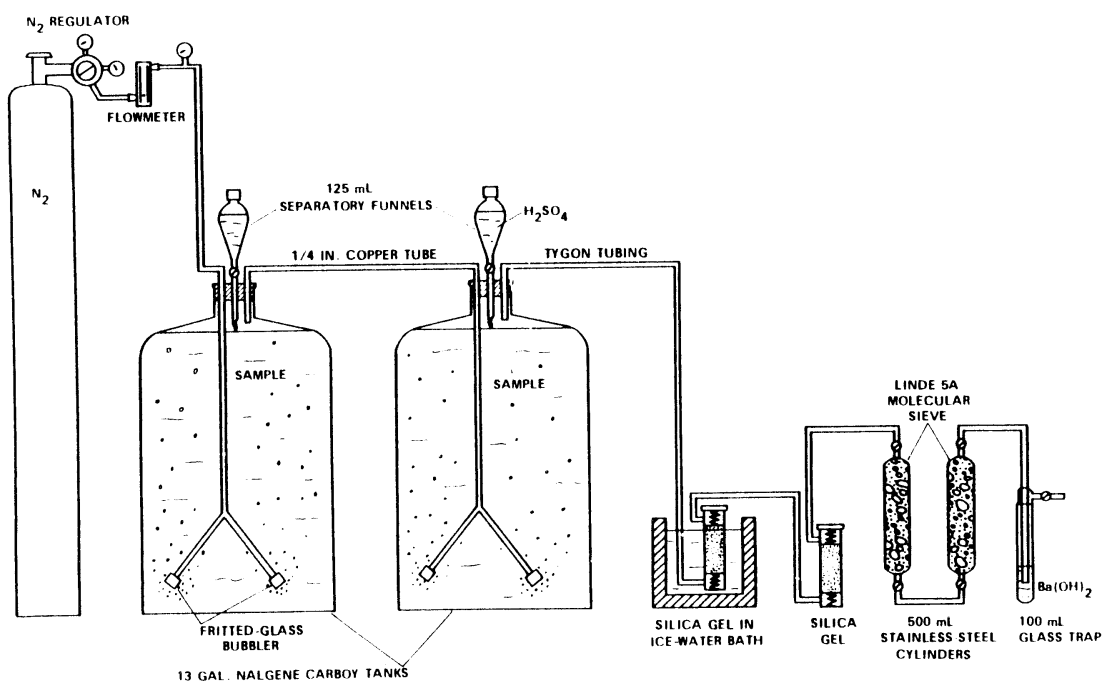

Fig 1. Carbon dioxide evolution system for extraction of dissolved carbonate species from natural water

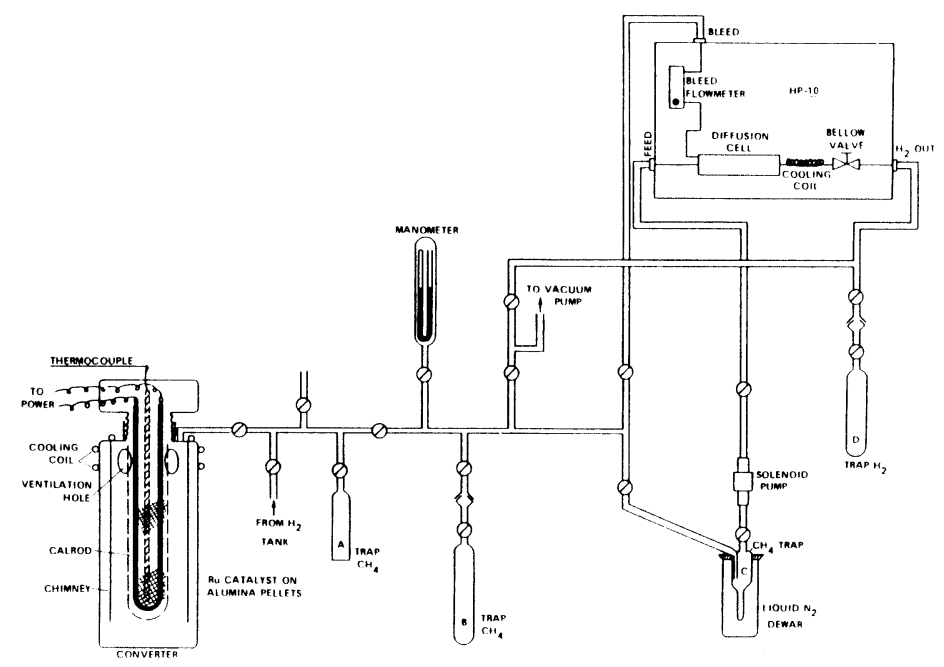

Fig 2. Carbon dioxide to methane conversion system 
SAMPLING-SITE STUDIES OF CARBON-ISOTOPE FRACTIONATION. The results of carbon-isotope fractionation by GEM are shown in the last column of table 3; the first cylinder collected the lighter carbon isotope, and the last cylinder collected the heavier carbon isotope (except in the instance of the second cylinder for sample $P R B$ 6). The second cylinder trapped lighter carbon isotope $\left(\delta^{13} \mathrm{C}=-24.2 \%\right.$ ) compared with the first cylinder $(-19.0 \%)$. The possible explanation is that the flow rate of $\mathrm{N}_{2}$ sweeping at the beginning of purging might have been too fast (not well controlled), resulting in the escape of $\mathrm{CO}_{2}$ from the first cylinder and collection in the second. After normal flow rate was established, most of the $\mathrm{CO}_{2}$ was collected in the first cylinder. Table 3 demonstrates that only $1 \%$ of $\mathrm{CO}_{2}$ was collected in the second cylinder compared with $28 \%$ collected in the first cylinder.

\section{DIRECT-PRECIPITATION METHOD (DPM)}

A groundwater sample of $140 \mathrm{~L}$ was collected in the conicalshaped precipitation tank with a 2L Mason jar screw-attached to the bottom of the tank. A top plate was provided to seal the tank from contact with the atmospheric $\mathrm{CO}_{2}$ and a stirrer also was provided to mix the content uniformly. Barium chloride $\left(\mathrm{BaCl}_{2}\right)$ or strontium chloride $\left(\mathrm{SrCl}_{2}\right)$ were used to precipitate the carbonate as $\mathrm{BaCO}_{3}$ or $\mathrm{SrCO}_{3}$; the precipitate was collected in the Mason Jar. After several hours of standing, the valve directly above the jar was closed, the top was unscrewed, capped immediately, and edges sealed with tape. The jar was sent to the laboratory.

Samples for carbon-isotope fractionation study were precipitated in four batches of approximately equal volumes of carbonate by adding $1 / 4$ of the required amount of $\mathrm{SrCl}_{2}-\mathrm{NH}_{4} \mathrm{OH}$ solution to the sample water each time. In the laboratory, carbonate precipitate was acidified with phosphoric acid $\left(\mathrm{H}_{3} \mathrm{PO}_{4}\right)$ to generate $\mathrm{CO}_{2}$ gas for mass-spectrometric analysis. The results are shown in table 3 . There are very few differences among the four fractions in both samples as indicated by the ${ }^{13} \mathrm{C}$ values. The decrease in heavier isotopes from the first fraction toward the fourth fraction also is evident in both instances. However, the difference is only a fraction of $1 \%$.

COMPARISON OF $\delta^{13} \mathrm{C}$ VALUES BETWEEN DPM AND GEM

Results of GEM invariably are isotopically lighter than those of DPM. The difference for sample PRB 6 between the two methods is $3 \%$, whereas for sample PRB 11 , the difference is only $1.2 \%$. This can be explained by examining the processes 
of fractionation in some detail. Strontium sulfate ( $\left.\mathrm{SrSO}_{4}\right)$ precipitates with $\mathrm{SrCO}_{3}$. The increase in sulfate concentration decreases the carbonate-precipitate yield because the amount of $\mathrm{SrCO}_{3}$ precipitated does not vary linearly with the amount of $\mathrm{SrCl}_{2}$ added; this process precipitates the heavier carbon isotope and leaves behind the lighter carbon isotope in the solution. Hassan (1982) found that the increase in the sulfate concentration to 0.01 molar decreases the efficiency of carbonate recovery to $90 \%$ by precipitation; thus, the heavier carbon isotope by DPM compared to GEM (which collects $95 \%$ or more) is observed. In contrast, GEM generates isotopically lighter carbon at the beginning of the process and heavier isotopes at the end. Consequently, incomplete recovery of carbon results in lighter $\delta^{13} \mathrm{C}$ values. The two processes enhance each other yielding even larger differences for the two methods if complete recovery of inorganic carbon is not attained. These processes partly account for the isotopically heavier $\delta^{13} \mathrm{C}$ values by DPM compared to GEM in table 3 .

\section{THE SMALL BENZENE SAMPLE}

In the laboratory, $\mathrm{CO}_{2}$ is allowed to react with metallic lithium ( $\mathrm{Li}$ ) to produce lithium carbide $\left(\mathrm{Li}_{2} \mathrm{C}_{2}\right)$, which is then hydrolyzed to produce acetylene $\left(\mathrm{C}_{2} \mathrm{H}_{2}\right)$. The acetylene is then passed over a Mobil Durabead catalyst ${ }^{1}$ to form benzene $\left(\mathrm{C}_{6} \mathrm{H}_{6}\right)$. Benzene is placed in Teflon vials and counted on liquid-scintillation counters (Yang and Emerson, 1980). For clean carbonate precipitate, the $\mathrm{CO}_{2}-\mathrm{C}_{2} \mathrm{H}_{2}$ conversion step normally results in $>95 \%$ efficiency and ca $88 \%$ efficiency in the $\mathrm{C}_{6} \mathrm{H}_{6}$ step. However, in quite a few instances, impure gas generated from the acidification of carbonate precipitate poisons the $\mathrm{Li}$, resulting in low yields on subsequent steps of $\mathrm{C}_{2} \mathrm{H}_{2}$ and $\mathrm{C}_{6} \mathrm{H}_{6}$ syntheses. In other instances, small $\mathrm{C}_{6} \mathrm{H}_{6}$ samples were obtained due to low carbonate concentrations in the ground water itself. From preliminary sampling-site data, indications were that GEM invariably yielded more $\mathrm{C}_{6} \mathrm{H}_{6}$, probably because of the cavity size of the molecular sieve that trapped the $\mathrm{CO}_{2}$ and excluded other gases. More data are required to support the finding.

For small samples, gas counting is preferred over liquidscintillation counting. Methane gas is used as a counting gas, because the same system also can be used to assay tritium activity. In 1980 a $\mathrm{CO}_{2}-\mathrm{CH}_{4}$ conversion system was developed that was similar to the design of Buddemeier et al (1970), except that model $\mathrm{HP}-10$ is used in $\mathrm{CH}_{4}$ purification instead of the A-5 palladium diffusion cell. Other modifications also were made on the converter and $\mathrm{CH}_{4}$-gas trap (fig 2). For a $4 \mathrm{~L} \mathrm{CO}_{2}$ sample, the conversion can be accomplished in $3 \mathrm{hr}$ with 
a 98\% yield. The proportional counters are similar to those of previous designs at the Quaternary Research Center of the University of Washington in Seattle (Stuiver, Robinson, and Yang, 1979).

\section{CONCLUSION}

GEM for extracting carbonate species from a large volume of ground water for ${ }^{14} \mathrm{C}$ dating is little affected by the presence of high concentrations of sulfate ions, is less susceptible to contaminations from atmospheric $\mathrm{CO}_{2}$, is less timeconsuming, and results in a higher yield. Thus, GEM is a better method for ${ }^{14} \mathrm{C}$ determination than DPM. However, possible large carbon-isotope fractionation by GEM, which is ca $1.1 \%$, can be avoided by sweeping with carrier gas at a flow rate of $2000 \mathrm{~cm}^{3} / \mathrm{min}$ for 3 to 4 hours. A separate $500 \mathrm{ml}$ water sample should be collected for ${ }^{13} \mathrm{C} /{ }^{12} \mathrm{C}$ analysis by DPM to calculate the contributions of various sources of dissolved carbonate species to the ${ }^{14} \mathrm{C}$ ages.

\section{REFERENCES}

Buddemeier, RW, Young, AY, Fairha11, AW, and Young, JA, 1970, Improved system of methane synthesis for radiocarbon dating: Rev Sci Instruments, v 41, no. 5, p 652-654.

Fairha11, AW, Young, AW, and Bradford, PA, 1972, Radiocarbon in the sea, in Rafter, TA and Grant-Taylor, T, eds, Internat 1 ${ }^{14} \mathrm{C}$ conf, 8th, Proc: Wellington, Royal Soc New Zealand, p C2-C16.

Fergusson, GJ, 1963, Upper tropospheric carbon-14 levels during spring 1962: Jour Geophys Research, v 68, p 3933-3941.

Gleason, JD, Friedman, I, and Hanshaw, BB, 1969, Extraction of dissolved carbonate species from natural water for carbonisotope analysis: US Geol Survey Prof Paper 650-D, pD248-D250.

Hassan, AA, 1982, Methodologies for extraction of dissolved inorganic carbon for stable carbon-isotope studies-Evaluation and alternatives: US Geol Survey Water Resources Inv, 82-6, 51p.

Stuiver, M, Robinson, SW, and Yang, IC, 1979, Carbon-14 dating to 60,000 years BP with proportional counters, in Berger, $\mathrm{R}$ and Suess, HE, eds, Radiocarbon dating, Internat1 ${ }^{14} \mathrm{C}$ conf, 9th, Proc: Berkeley, Univ California Press, p 202-215.

Thatcher, LL, Janzer, VJ, and Edwards KW, 1977, Carbon-14, dissolved, apparent age, liquid scintillation method, Denver Laboratory: US Geol Survey Techniques of Water Resources Inv, Bk 5, Chap A5, p 17-22.

Yang, IC and Emerson, RL, 1980, Teflon vials for low-level carbon-14 1iquid scintillation counting, in Peng, Horrocks, and Alpen, EL, eds, Liquid scintillation counting: recent applications and development: New York, Academic Press, v 2, p 181-197.

Voge1, JC, Lerman, JC, and Mook, WG, 1975, Natural isotopes in surface and groundwater from Argentina: Bull Hydrol Sci, v 2C p 203-221. 